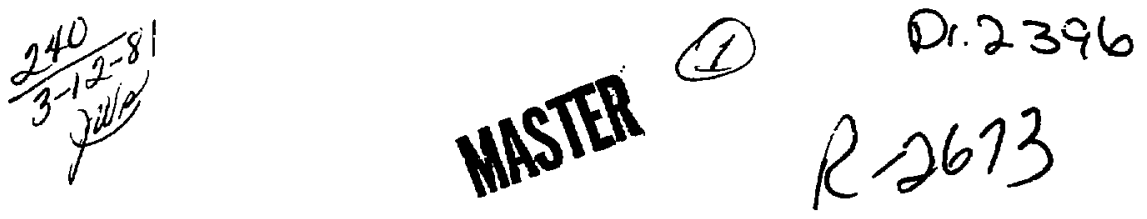

Dose to man from a hypothetical loss-ofcoolant accident at the Rancho Seco nuclear power plant

Kendall R. Peterson

George D. Greenly

February 1981

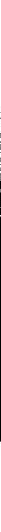




\title{
Dose to man from a hypothetical loss-of- coolant accident at the Rancho Seco nuclear power plant
}

\author{
Kendall R. Peterson \\ George D. Greenly
}

Manuscript date: February 1981

LAWRENCE LIVERMORE LABORATORY

University of California $\cdot$ Livermore, California $\cdot 94550$ 


\section{CONTENTS}

\section{Page}

Abstract . . . . . . . . . . . . . . . . . . l

Introduction. . . . . . . . . . . . . . . . . l

Deseription of Computer Models . . . . . . . . . . . . . . 2

Input Data . . . . . . . . . . . . . . . . . . . 4

Release Rates . . . . . . . . . . . . . . . . . 4

Physical Parameters. . . . . . . . . . . . . . . . . . . . . 4

Meteorology . . . . . . . . . . . . . . . . 4

Dose-Conversion Factors. . . . . . . . . . . . . 5

Other Input. . . . . . . . . . . . . . . . . . . 6

Results of Calculations . . . . . . . . . . . . . . . . 6

Discussion. . . . . . . . . . . . . . . . . . . . 11

Washout .....................11

"horst Case"................... . . 12

Error Analysis . . . . . . . . . . . . . . . 12

Comparison with Three Mile Island Accident . . . . . . . . . 13

Summary . . . . . . . . . . . . . . . . . . . . 13

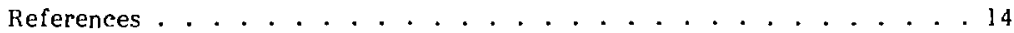




\title{
Dose to man from a hypothetical loss-of-coolant accident at the Rancho Seco nuclear power plant
}

\begin{abstract}
At the request of the Sacramento Municipal Utilities District, we used cur computer codes, MATHFW and ADPIC, to assess the environmental impact of a loss-3f-coolant accident at the Rancho Seco Nuclear Power Plant, about 40 kilometres southeast of Sacramento, California. Metenrological input was selected so that the effluent released by the accident would be transported over the Sacramento metropolitan area.

With the release rates provided by the Sacramento Nunicipal Utilities District, we calculated the largest total dose for a 24-hour release as 70 rem about one kilomictre northwest of the reactor. The largest total dose ${ }^{*}$ in the Sacramento metropolitan area is 780 millirem. Both doses are from iodine-13l, via the forage-cow-milk pathway to an infant's thyroid. The largest dose near the nuclear plant can be minimized bv replacing contamirated milk and by giving the cows dry feed. To our kiluwledge, there are no milk cows within the Sacramento metropolitan aren.
\end{abstract}

\section{INTRODUCTIO}

The Rancho Seco Nuclear Power Plant, iocated about $40 \mathrm{~km}$ southeast of Sacramento, California, was first put on line in 1974 at a power rating of 913 Milie. The reactor is of the pressurized water $(P W R)$ type and provides elcetric power to the central valley grid.

The Rancho Seco plant is operated by the Sacramento Nunicipal Utilities listrict (SAIUI)) in Sacramento. At the request of SHUU, the Atmospheric and Geophycical Sciences Livision of the l.awrence I.ivermore Nationil lahoratory has used its MATHEK/ADPIC computer codes to assess the environmental impact to man, through various pathways, from a loss-of-coolant accident (1.OCA) at the Rancho Seco power reactor. SMLD asked that this assessment be made using input winds that would transport reactor effluents over the Sacramento metropolitan area, i.e., winds from the southeast, for up to 24 hours. Prolonged southeast winds oceur most frequently during winter in this part of the Central Vallev.1-3

The annual frequency of wind direction and the average wind speed observed at Rancho Seco's 10-m meteorological tower from 1974 to 1978 are shown in Table 1. The most frequent wind direction is from the west (almost $12 \%$ ). Southeast winds occur $8 \%$ of the time at an average speed of $3.5 \mathrm{~m} / \mathrm{s}$. Figure 1 is a graph of these wind frequencies.

\footnotetext{
* In this report, dose refers to the committed dose equivalent to an individual, according to the definition given by the International Commission on Radiological Protection.
} 
TABI.F. L. Frequency (percent) and average speed $(\mathrm{m} / \mathrm{s})$ of $10-\mathrm{m}$ wind directions at kancho seco for all months, 1974 to 1978.

\begin{tabular}{|c|c|c|}
\hline hinc direction & lirequency, $\bullet$ & Average speed, $\mathrm{m} / \mathrm{s}$ \\
\hline $\mathrm{N}$ & 3.0 & 2.4 \\
\hline$N N F$ & 2.5 & 2.0 \\
\hline $\mathrm{NE}$ & 3.0 & 1.4 \\
\hline $\mathrm{FNE}$ & 3.5 & 1.4 \\
\hline $\mathrm{F}:$ & 3.8 & 2.2 \\
\hline ISE: & 5.7 & 2.9 \\
\hline Sil: & 8.0 & 3.5 \\
\hline Si, & $\because+h$ & 4.3 \\
\hline$S$ & 7.4 & 2.8 \\
\hline $\sin$ & 4.8 & 2.6 \\
\hline sh & 7.7 & 3.11 \\
\hline USH & 9.6 & 3.4 \\
\hline u & $11 . k$ & 3.6 \\
\hline$\| \wedge n$ & 5.2 & 3.1 \\
\hline $\mathrm{Nh}$ & $a+7$ & 3.4 \\
\hline$N N h$ & 5.8 & 4.5 \\
\hline$(3)$ & 11.8 & 0.11 \\
\hline
\end{tabular}

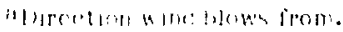

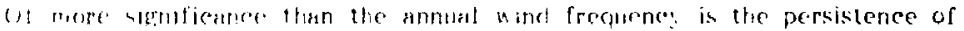

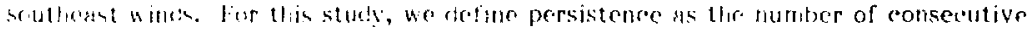
heurs that the numa hancho Sceg hlows from the same ?2.5-degree sector. Five years of these chata, provide by SMLI, 3 are slown by month in table 2 for winds from the cast-southeust, southegst, anci south-southegst. For cast-southeast ard

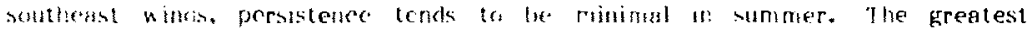

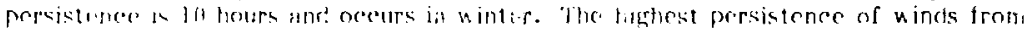

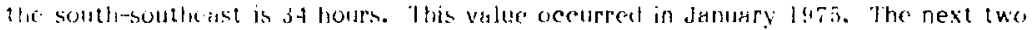
lower vilues curme the five-year pee ind were 2 ? and 21 houra.

Although we have rut made an explicit trajectorv study, the winds could be south-southerst it Ranchk Srea and southeast or east-southeist un sucremento for nany hours. This could result in an effluent trajectory from a loss-ot-coolant tace: lent that would affect the Sucramento metropolitan area. Hased on five years of data, the probatidity of sonth-sontheast winds for 34 hours at Rancho Sero is about $10^{-3}$. The combined frequency of such wind dircetions and long persisterice values at both Rancho seco and Sacramento is loss then $10^{-3}$.

\section{DESCRIPTION OF COMPL,TER MODFLS}

A suite of three-dimnnsic nal computer rodes was used to preparn the close isopleth pHtterns presented in this report. The tno major codes in this suite are MATHF 4,4 a program that acjusts observed horizontul winds, using variational analysis methods, 5 to conserve mass from cell to cell, and Ample, $F^{\circ}$ a Cartesian purticle-in-cell codc used to enlculate the transport and diffusiun oi effuents an a 
TABIF: 2. Maximum monchiy persistence of east-southeast, southeast, and southsoutheast wind directions in hours at the $10-\mathrm{m}$ Rancho Seco tower, 1974 to 1978.

\begin{tabular}{|c|c|c|c|c|c|c|c|c|c|c|c|c|c|}
\hline Year & Jan & Feb & Mar & Apr & May & Jun & Ju] & Aug & Sep & Oct & Nov & Dec & $\begin{array}{l}\text { Ann. } \\
\max \text {. }\end{array}$ \\
\hline \multicolumn{14}{|c|}{ East-Southeast $\mathrm{W}$ ind } \\
\hline 1974 & 6 & 4 & 7 & 6 & $?$ & 2 & 2 & 3 & 1 & 5 & 8 & 6 & 8 \\
\hline 1975 & 4 & 5 & f & 5 & 3 & 3 & 2 & 2 & 2 & 7 & 6 & 5 & 7 \\
\hline $197 t$ & F & 5 & $g$ & 4 & 3 & ? & I & 7 & 2 & 5 & 3 & 6 & 8 \\
\hline 1978 & fi & 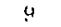 & $i$ & 3 & 2 & 2 & 3 & 3 & 4 & 4 & 4 & 5 & 9 \\
\hline $14 \% 8$ & fi & 4 & \% & 9 & 8 & 3 & 3 & F & 4 & 4 & 4 & 5 & 9 \\
\hline \multicolumn{14}{|c|}{ Southeast Wind } \\
\hline $14: 4$ & in & 6 & 4 & 7 & 3 & 3 & 2 & ] & 5 & 10 & 6 & 6 & 10 \\
\hline | & $i$ & 10 & 5 & 8 & 3 & ? & 3 & 3 & 3 & 5 & 8 & 5 & 10 \\
\hline 1976 & ? & $?$ & i & $\vdots$ & 5 & 4 & 3 & 3 & 4 & 6 & 3 & 6 & i \\
\hline 1977 & 4 & 6 & 8 & $i$ & 3 & 2 & 3 & 2 & 3 & 6 & 7 & $x$ & 8 \\
\hline 14,8 & - & 2 & 6 & 5 & 3 & 8 & 4 & 3 & i & 3 & 3 & 4 & 8 \\
\hline \multicolumn{14}{|c|}{ South-Southeast hind } \\
\hline 1971 & | 1 | & 11 & 22 & 13 & 4 & 3 & 4 & $i$ & 2 & 9 & 8 & $: 1$ & $\therefore 2$ \\
\hline $1 ! 5 \div$ & 34 & 21 & 12 & 6 & 4 & 4 & 4 & 3 & 3 & 6 & 4 & $n$ & 34 \\
\hline 1456 & $\mathrm{ti}$ & 7 & 11 & 5 & 4 & 3 & 5 & $f$ & 4 & 3 & 12 & 4 & 12 \\
\hline $14: 7$ & 15 & 5 & 12 & ו & 6i & 5 & 8 & 3 & 4 & 5 & 10 & 10 & 15 \\
\hline 1978 & 18 & 4 & f & 5 & 3 & 3 & 6 & 4 & 3 & 4 & 2 & 3 & 18 \\
\hline
\end{tabular}

regional scale. Allple ran handle diffusion with both. horizontai arse vertucal $n$ ind shcirs, variatle surfuce roughness, dry and wet deposition, radioactive decay, and space- and time-variable diffusion parameters. Particles, simulating pollutants lup 1025,000 can be generated), move in a I.agrangian reference frame through an Fulerian grid. The main advantage of particle-in-cell technigues is that the problem of artificial diffusion, common to most Fulerian frids, is eliminated. Aluple calculations have agreed within 5 o of existing closed-form analytic solutinns. l'sing observed site-sDecific meteorological data, ADPIr calculations have agrecd within factors of two or three of surface and helicopter observations. The deviations brtwcen calculations and observations are due to both metcorological and sanpling crrors, as well as to uncertainties about nonmeteorological infut parameters, such as surface joughness and deposition velocity.

In pasi studies, calculations using the MATHFW-A[IPIC suite of codes for flat terrain have agreed within a factor of three with continuous-point-source (iaussian diffusion (CPS $)^{7}$ results for plume centerine doses. Off-axis estimates usually deviate more; the MATHFh-ANPIC results have agreed better than CPS with past tracer studies. 


\section{INPIT DATA}

\section{Release Rates}

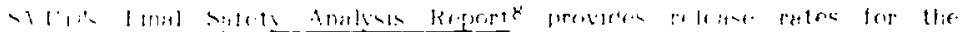

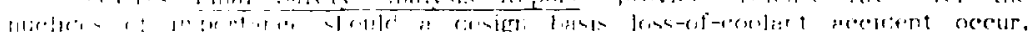

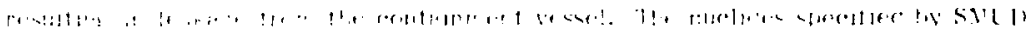

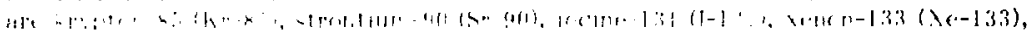

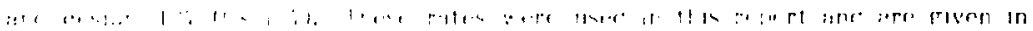
$1 \cdot 1 \cdot i \cdot$

\section{l'hisical Parame'ters}

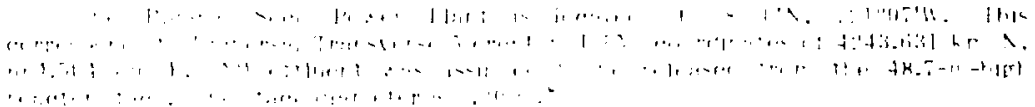

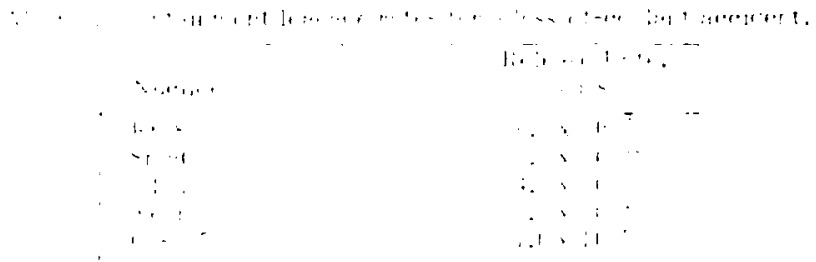

\section{Weterralon!}

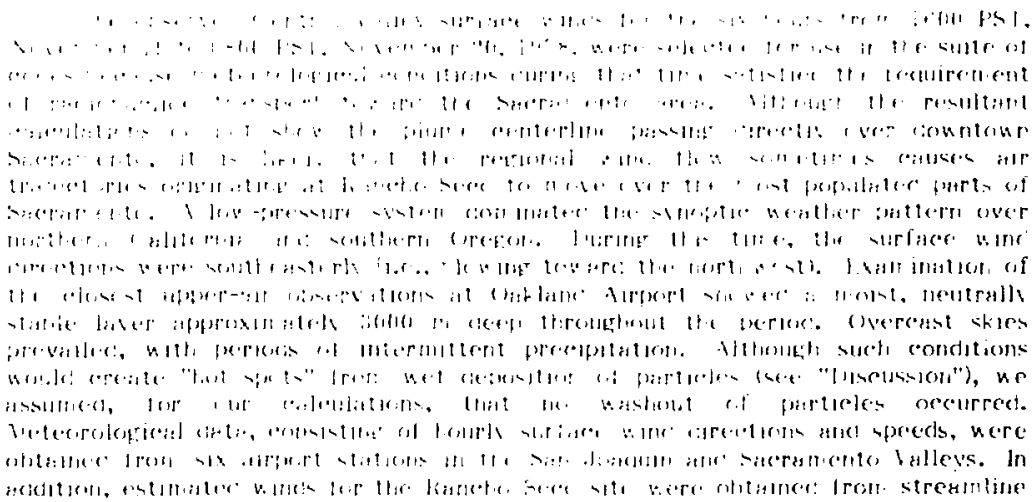


analyses, using nearby National heather Service stations. The locations of these observing stations are shoun in Fig. 2. The wind arrows blow with the winds; these ninds were measured at 2200 PST, Novemher 19, 1978.

Since we needed onservations of southeast winds for 34 hours, the surface data used after 0800 PST, Novemher 20, was obtained via persistence of the wind field at 0800 PSI on Novemher 26 through 1600 PST, Novertber 20. Surface and upper air dnta user from 1700 PST, November 20 to 0100 PST, November 21. 1978 wer: a rсpegt of the data 24 hours prior. This resulted in a worst-case situation for the particular data set usec. The top of the mixing layer nas placer subjectively at 500 11. itter both the mestn winter mixing beights? for the ares and the sunoptic sithation spanning 34 hours of transport and diffusion were considered. This mixing

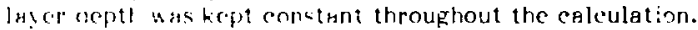

\section{Dose-Conersion Factors}

I" craluate the dose to man vis various pathwyys, we multiply thlir-integratex: surface-concentration and depositicn calculations by appropriate

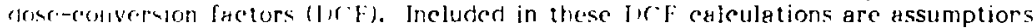
of such, 11 mus is the foogy ard organ masses and breathing and ingestion rates of a "stafkurc: Ir at." lypical rattle grazing areas, and the time bethorn the exposure to "H leve: ururer anc: the ronsimption of that fooc by tumans. A sfi-year dose comblt at following a short exposure uas assun ed.

1 or llis rep'rt, we have macie ealculations for the lareces doses to man. consiceralle ige and organ, for the puthusys shoun helov. Adult refers to it 20 loar

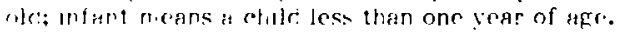

- Ixtcrnal gamithit. Ihs is griven is the parts: the coner trom mmersion in

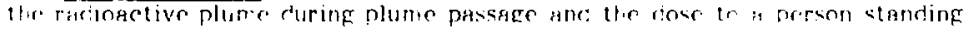

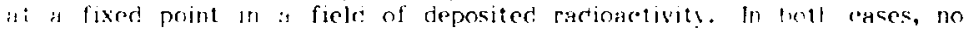

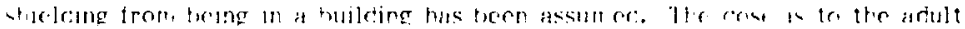
wholo hos:y.

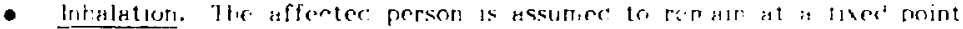
during plume passage. His inhalation results in sose to the lungen and to other organs due to translocation from the lungs. The dose th the astult bone in

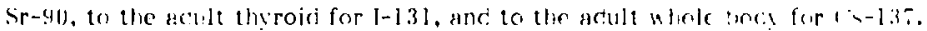

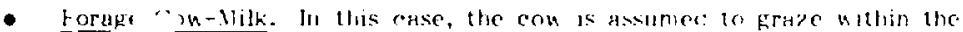
ceposition lede, and the person is assumed to trink pilk nuly fror cows that have grazed in that ares. in reality, except for family cons, nearly all milk today is pooled and distributed by couperatives; hence the andiskul wnuld

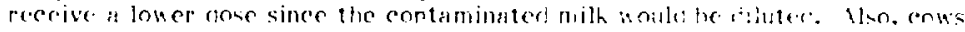

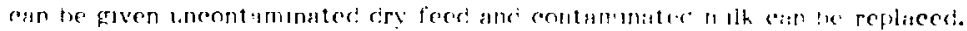

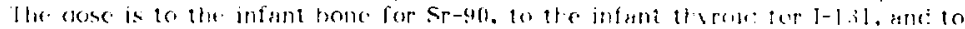
She infunt ahe'e boug lor ('s-lat.

- Pasture-Nleat. This pathury applies to beef eatcle. It is assumec that the cattle graze in the sume area and are slaughteres shorlly after consuming grass contaminter hy the nuciides released hefore s'lfficiert time has elapsed for the animal to eliminate the radinactivity from its hody. Tro dose is to the 
adult hone for Sr-40, to the adult thyroid for I-131, and io the adult whole borly for $\mathrm{r}^{\mathrm{s}} \mathrm{s}-\mathrm{i} 3$ ?.

- I.eafy legethtule. Ihis pathuay applies to stich crops as lettuce and cabbuge. It is assunied that the irrigation water is uncontaminated. the vegetables are consumed (without prier washing) one cay after the expostre, and there is no uplatie fromi the soil, through the ronts, to the plant's leaves. The ruse is to thr adult bone for Sr-90, to the acolt thyroid for $1-131$, ane to the adult wiole hody for ('s-13t.

The dose-remversion factors used in this sturly for all nuclides considered and

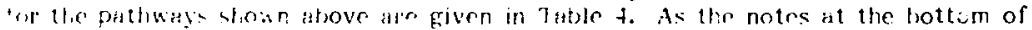

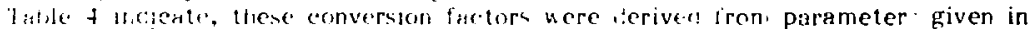

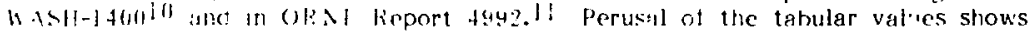

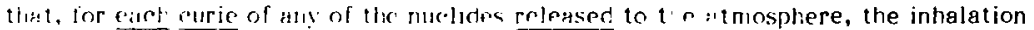

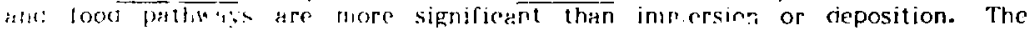

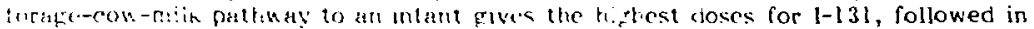
tres 5 it linportince by the nusture-meat patt for $1-131$ to an adult. The doses that

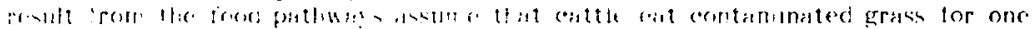

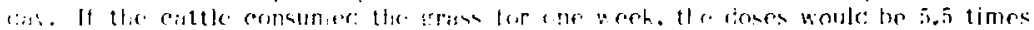

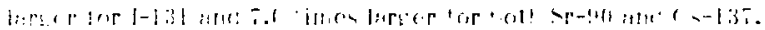

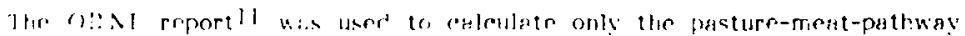
rese-conversion pactora. Wr foll that the Hasil-14n0 trentment of the

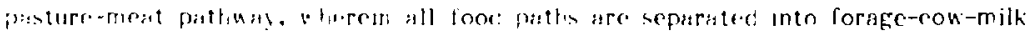

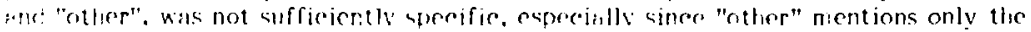

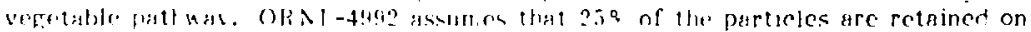

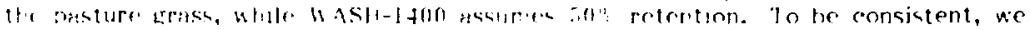

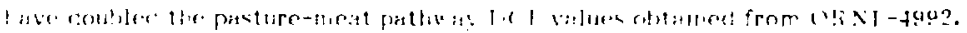

\section{Other Input}

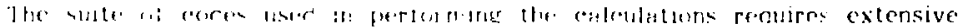

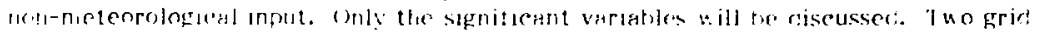

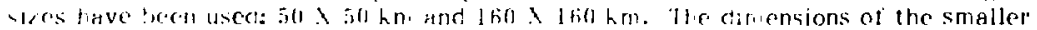

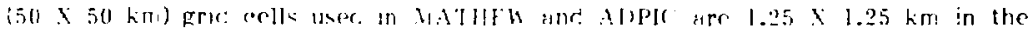

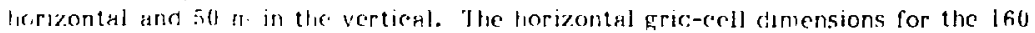

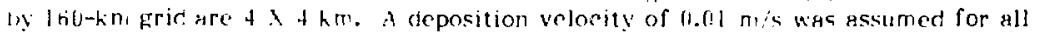
particulate muelices. Iliss velocity should not te confusea uith a gravitational fall velocity. The iattor velocity was ret to zero since the particle ratii were assumed to the 5 Hm; nurticles of this size closely follon the nir flow, and the effects of turbulence near the ground overshadow their small fail velocity. The surface-roughness height, which is depentent on the nature of the surlace and determines the depositici rate, was assunies to the $1.03 \mathrm{n}$; this value is lypical of norly flut farm lani nith isolated huldings ald trees.

\section{RFSI I.SS OH CAICI IATHONS}

Calculations, as requested by sull, were performed, using the liATHFW/ Aliple suite of endes on the Iuwrenee livermore I.8boratorv's CDr 7600 


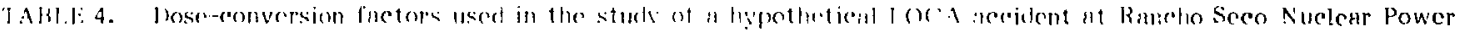
Plant.

\begin{tabular}{|c|c|c|c|c|c|c|c|}
\hline \multirow[b]{2}{*}{ Nuelide } & \multirow[b]{2}{*}{$\begin{array}{l}\text { lyIf- } \\
\text { life- }\end{array}$} & \multicolumn{2}{|c|}{ Extcrmal Cinmont } & \multirow{2}{*}{$\begin{array}{l}\text { Inhalationn } \\
\frac{m r(m / s}{(i / m)^{3}}\end{array}$} & \multirow{2}{*}{ 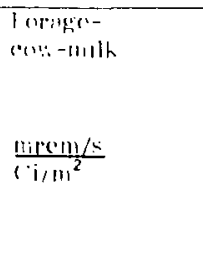 } & \multirow{2}{*}{$\begin{array}{l}\text { Pastl. b- } \\
\text { menil } \\
\frac{\operatorname{moc} n / s}{\mathrm{i}_{i} \|^{2}}\end{array}$} & \multirow{2}{*}{$\begin{array}{l}\text { Teafy- } \\
\text { vegeinule } \\
\frac{\mathrm{mrem} / \mathrm{s}}{\mathrm{i} / \mathrm{m}^{2}}\end{array}$} \\
\hline & & $\begin{array}{l}\text { Immorsion } \\
\text { lursm/- } \\
\left(" 1 / \mathrm{m}^{3}\right. \\
\text { (adult wholc } \\
\text { body) }\end{array}$ & 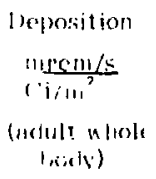 & & & & \\
\hline$S_{r}-40$ & $24.11 \mathrm{y}$ & 1) & 1) & $\begin{array}{l}7.5 \times 10^{5} \\
\text { (acinilt home) }\end{array}$ & $\begin{array}{l}\text { (i. } 4 \times 10^{8} \\
\text { (jurlunt benc) }\end{array}$ & $\begin{array}{l}\text { (i.fi } \times 10^{8} \\
\text { (adult bone) }\end{array}$ & $\begin{array}{l}5.5 \times 10^{8} \\
\text { (adult bone) }\end{array}$ \\
\hline 1.131 & R.A d & $8.7 \times 11^{1}$ & $1 . \therefore \times 11^{0}$ & $\begin{array}{l}3.1 \times 1 n^{5} \\
\text { (notult } . \text { aid })\end{array}$ & $\begin{array}{l}\text { fi.3 } \times 10^{9} \\
\text { (imfant (hyroit) }\end{array}$ & $\begin{array}{l}\text { T.tix } 10^{7} \\
\text { (nciult llyroid) }\end{array}$ & $\begin{array}{l}3.1 \times 10^{8} \\
\text { (ndult thyroid) }\end{array}$ \\
\hline
\end{tabular}

Note.

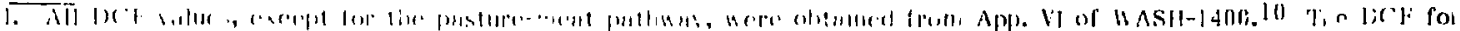

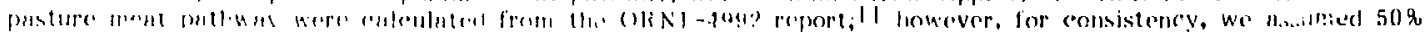

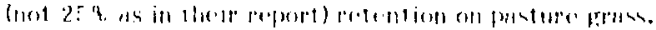

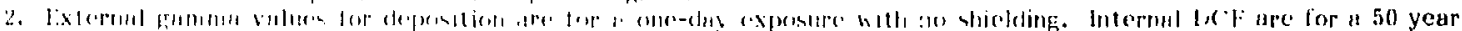

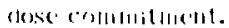

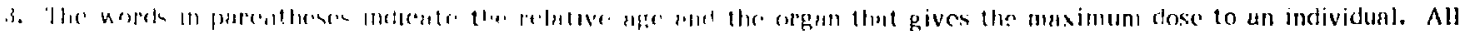

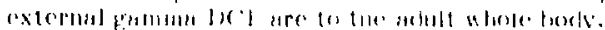

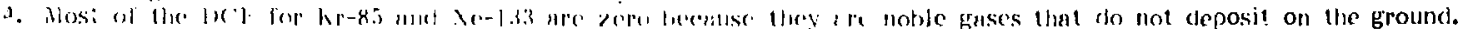

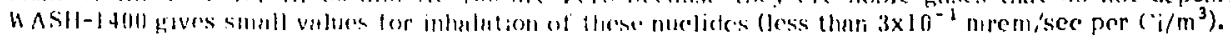

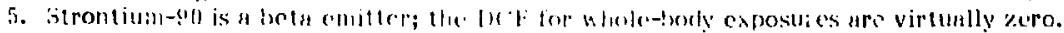


computers. The scenarios used are given in Table 5. The pathways of dose to man considered are external gamma (immersion and deposition), inha]ation, forage-cow-milk, pasture-meat, and leafy vegetable.

Tables $6 A$ and $6 B$ list the celculated maximum values (near the reactor) and the largest values within Sacramento (in millirem) for individual nuclides and pathways. The maximum values are about one kilometre northwest of the plant. The AIPPIC code cannot accurately resolve air concentrations and deposition within the grid cell (of $1.25 \times 1.25 \mathrm{~km}$ ) that contains the source; therefore, the values in Table $6 A$ were obtained with the Gaussian continuous-point-source (CPS) code. 7 Sector-tucraging was used for the 24-hour release, but not for the 2-hour retease. Those unput parameters thet are common to ADPIC and CPS were made identical for the (PS calculatiuns. Within a few kilometres downwind, the plume's lateral growth was such that the ADPl calculations became superior to the CFS calculations. Fifrures 3 to 21 are computer-generated plots of the dose to man. For pathways other thin immersion, I-13I gives the largest doses by [ar, and these plots may be used as total dose plots from all nuclides. The axes of all contour plots are labcled in L'Tn! coordinates and are in kilometres. Major roads are also shown on the maps as snlic lines; dotted lines delineate the boundary of the Sacramento motropolitan area, as well as aqueducts, lakes, and rivers. The three-letter desigmato's represent ajrport observation sites, except for RSO, which is our abticuiation for the Raneho Seco site.

The 2- and 24-hour colltinuous release conditions, plus the need for 34 hours of meteorolngiral data sets, dictated a grid structure that placed the release point within the firs: vertical diffusion cell. The number of meteorological data sets placed a significant restriction on the overail grid size and on whether topographical features were to he considered.

16e assumed a flat frid (with no terrain features). Inrluding the actual terrain in the modcl ralculations would have inereased the running time of the computer codes and, because of the relatively level character of the Central Valley, would not have increased the juality of the model output significantly. A 50-by 50-km grid was used in all calculations. When the maximum dose is one millirem or greater, $160-$ by lfi-km grids are included to depict the dose isopleths beyond the Sacramentó metropolitan area.

IABLE 5. I.OCA scenarios requested by the Sacramento Municipal Utilities bistrict.

\begin{tabular}{|c|c|c|c|c|}
\hline $\begin{array}{l}\text { Sccnario } \\
\text { number }\end{array}$ & $\begin{array}{c}\text { Nuclides } \\
\text { considered }\end{array}$ & $\begin{array}{c}\text { Iength of } \\
\text { release, } h\end{array}$ & $\begin{array}{c}\text { Length of transpo-t } \\
\text { and diffusion } \\
\text { calculations, } h\end{array}$ & Pathway \\
\hline 1 & Alla & 2 & 24 & Immersion \\
2 & All & 24 & 34 & $\begin{array}{c}\text { All b } \\
3\end{array}$ \\
4 & Individually & 2 & 24 & All \\
\hline
\end{tabular}

A All refers to the total dose from $\mathrm{Kr}-85, \mathrm{Sr}-90,1-131, \mathrm{Xe}-133$, and $\mathrm{Cs}^{-137}$.

b pathways are external gamma (immersion and deposition), inhalation, forage-cow-milk, pasture-meat, and leafy vegetable. 
TABI,E 6. Dose vs pathway for nuclides released from the Rancho Seco Power Plant during a hypothetical loss-of-coolant accident. See notes at bottom for explanation of parentheses, dashes, and missing values in "All" rows.

A. Maximum doses (in millirem) about one kilometre nor thwest of Rancho Seco.

\begin{tabular}{|c|c|c|c|c|c|c|}
\hline \multirow[b]{3}{*}{ Nuclide } & \multicolumn{6}{|c|}{ Pathway } \\
\hline & \multicolumn{2}{|c|}{ Fxternal Gamma } & \multirow[b]{2}{*}{ lnhalation } & \multirow{2}{*}{$\begin{array}{l}\text { Forage- } \\
\text { cow-milk }\end{array}$} & \multirow{2}{*}{$\begin{array}{c}\text { Pasture- } \\
\text { meat }\end{array}$} & \multirow{2}{*}{$\begin{array}{c}\text { Leafy } \\
\text { vegetable }\end{array}$} \\
\hline & Immersion & Teposition & & & & \\
\hline $\mathrm{Kr}-85$ & $\begin{array}{c}7.8 \times 10^{-4} \\
\left(1.5 \times 10^{-4}\right)\end{array}$ & -- & $-\infty$ & - & - & - \\
\hline Sr-90 & -- & -- & $\begin{array}{c}2.3 \times 10^{-5} \\
\left(4.4 \times 10^{-6}\right)\end{array}$ & $\begin{array}{c}2.0 \times 10^{-4} \\
\left(3.8 \times 10^{-5}\right)\end{array}$ & $\begin{array}{l}2.1 \times 10^{-4} \\
\left(4.0 \times 10^{-5}\right)\end{array}$ & $\begin{array}{l}1.7 \times 10^{-4} \\
\left(3.3 \times 10^{-5}\right)\end{array}$ \\
\hline$|-| 3 \mid$ & $\begin{array}{r}9.6 \times 10^{-2} \\
\left(1.8 \times 10^{-2}\right)\end{array}$ & $\begin{array}{c}1.5 \times 10^{0} \\
\left(2.9 \times 10^{-1}\right)\end{array}$ & $\begin{array}{c}3.5 \times 10^{2} \\
\left(6.7 \times 10^{1}\right)\end{array}$ & $\begin{array}{c}7.0 \times 10^{4} \\
\left(1.3 \times 10^{4}\right)\end{array}$ & $\begin{array}{c}8.5 \times 10^{2} \\
\left(1.6 \times 10^{2}\right)\end{array}$ & $\begin{array}{l}3.5 \times 10^{3} \\
\left(6.7 \times 10^{2}\right)\end{array}$ \\
\hline$x e-133$ & $\begin{array}{c}2.7 \times 10^{-1} \\
\left(5.1 \times 10^{-2}\right)\end{array}$ & -- & $=$ & $\rightarrow$ & & \\
\hline Cs-1 37 & $\begin{array}{r}3.1 \times 10^{-5} \\
\left(6.0 \times 10^{-6}\right)\end{array}$ & $\begin{array}{c}5.2 \times 10^{-4} \\
\left(9.5 \times 10^{-5}\right)\end{array}$ & $\begin{array}{r}2.9 \times 10^{-3} \\
\left(5.6 \times 10^{-4}\right)\end{array}$ & $\begin{array}{c}6.5 \times 10^{-1} \\
\left(1.2 \times 10^{-1}\right)\end{array}$ & $\begin{array}{r}5.7 \times 10^{-2} \\
\left(1.1 \times 10^{-2}\right)\end{array}$ & $\begin{array}{r}7.3 \times 10^{-2} \\
\left(1.4 \times 10^{-2}\right)\end{array}$ \\
\hline All & $\begin{array}{c}7.3 \times 10^{-1} \\
\left(6.9 \times 10^{-2}\right)\end{array}$ & $\begin{array}{c}1.5 \times 10^{0} \\
\left(2.9 \times 10^{-1}\right)\end{array}$ & & & & \\
\hline
\end{tabular}


TABI.1: 6. Continues;

B. Maximum doses (in millirem) within the Sacramento netropolitan area.

\begin{tabular}{|c|c|c|c|c|c|c|}
\hline \multirow[b]{3}{*}{ Nuclide } & \multicolumn{6}{|c|}{ Pathway } \\
\hline & \multicolumn{2}{|c|}{ External Gamma } & \multirow[b]{2}{*}{ Inhalation } & \multirow{2}{*}{$\begin{array}{l}\text { Forage- } \\
\text { cow'milk }\end{array}$} & \multirow{2}{*}{$\begin{array}{l}\text { Pasture- } \\
\text { meat }\end{array}$} & \multirow{2}{*}{$\begin{array}{c}\text { Leaîy } \\
\text { vegetable }\end{array}$} \\
\hline & Immersion & Deposition & & & & \\
\hline$K r-85$ & $\begin{array}{c}2.2 \times 10^{-5} \\
\left(1.2 \times 10^{-6}\right)\end{array}$ & - & - & - & - & - \\
\hline $\begin{array}{l}\mathrm{Sr}-90 \\
1-121\end{array}$ & $\begin{array}{c}8.9 \times 10^{-4} \\
\left(6.5 \times 10^{-5}\right)\end{array}$ & $\begin{array}{c}-- \\
1.5 \times 10^{-2} \\
\left(9.0 \times 10^{-4}\right)\end{array}$ & $\begin{array}{c}2.3 \times 10^{-7} \\
\left(1.7 \times 10^{-8}\right) \\
3.1 \times 10^{0} \\
\left(1.9 \times 10^{-1}\right)\end{array}$ & $\begin{array}{c}3.4 \times 10^{-6} \\
\left(3.9 \times 10^{-7}\right) \\
7.8 \times 10^{2} \\
\left(4.7 \times 10^{1}\right)\end{array}$ & $\begin{array}{c}3.5 \times 10^{-6} \\
\left(4.0 \times 10^{-7}\right) \\
9.5 \times 10^{0} \\
\left(1.7 \times 10^{j}\right)\end{array}$ & $\begin{array}{c}2.0 \times 10^{-6} \\
\left(3.3 \times 10^{-7}\right) \\
3.9 \times 10^{1} \\
\left(7.1 \times 10^{0}\right)\end{array}$ \\
\hline$x e-133$ & $\begin{array}{c}6.8 \times 10^{-3} \\
\left(4.1 \times 10^{-4}\right)\end{array}$ & - & - & - & - & 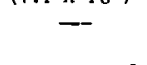 \\
\hline $\begin{array}{l}\text { Cs-1 } 37 \\
\text { All }\end{array}$ & $\begin{array}{c}2.9 \times 10^{-7} \\
\left(2.3 \times 10^{-8}\right) \\
7.7 \times 10^{-3} \\
\left(4.8 \times 10^{-4}\right)\end{array}$ & $\begin{array}{c}6.8 \times 10^{-6} \\
\left(7.3 \times 10^{-7}\right) \\
1.5 \times 10^{-2} \\
\left(9.0 \times 10^{-4}\right)\end{array}$ & $\begin{array}{c}2.5 \times 10^{-5} \\
\left(1.0 \times 10^{-6}\right)\end{array}$ & $\begin{array}{c}9.1 \times 10^{-3} \\
\left(8.7 \times 10^{-4}\right)\end{array}$ & $\begin{array}{c}8.0 \times 10^{-4} \\
\left(7.6 \times 10^{-5}\right)\end{array}$ & $\begin{array}{l}1.0 \times 10^{-3} \\
\left(1.1 \times 10^{-4}\right)\end{array}$ \\
\hline
\end{tabular}

Notes

1. F.ntries without par $=$ ntheses are for a 21 -hour release; those in parentheses are for a 2 -hour release.

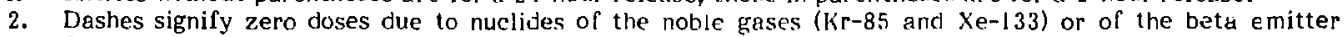
Sr-90.

3. The inhalation and ingestion pathways do not have entries in the bottom row. Since each nuclide affects a different organ, doses cannot be summed.

4. See Table $;$ for relative ages and organs that give the largest doses to an individual lor each nuclide and pathway shown. 


\section{DISCUSSION}

We have assessed the dose to man from a hypothetiral loss-of-coolant accident at the Rancho Seco Nuclear Power Plant, using nuclide source rates specified by the SMUD (Table 3). Table 6B indicates that, within the Sacramento metropolitan area, the largest dose is from [-]3] via the forage-cow-milk pathway to an infant's thyroid (780 millirem for a 24-hour release); the leafy-vegetable pathway for the same nuciite to an adult ranks second $(39$ millirem).* These food pathways are not credible for a metropolitan area, including its suburbs, except for family gardens. llence, when food pathways are neglected, the largest dose is 3.1 millirem from 1-. . 1 via inhalation for a 24 -hour release at the rate given in Table 3.

Closer to the Rancho Seco reactor, a loss-of-coolant accident would yield larger doses (see lable 6A). The maximum calculated dose, about one kilometre northwest of the Rancho Seco plant, is $70 \mathrm{rem}$ from I-l31 to the infant thyroid via the forage-cow-milk pathway. This value is about one-fourth of the 300-rem 1hyroid-dose accident eriteria specified in the Code of Federal Regulation, Tille 10, Chapter 100 . The next larger dose is 3.5 rem from J-131 to the adult thyroid via the eafy vegctable pathway.

The Envirormental Proteciion Agency (EPA) has developed Protective Action Guidelines' 2 for radiological emergercies. These Guidelines have been used in a joint report by the Nuclear Regulatory Commission and the Federal Emergency Management Afency. 13 Their report specifies response plans to bo used in the event of an accident at a nuclear power plent.

'The Ciuidelines specify that $(a)$ beyond $16 \mathrm{~km}(10 \mathrm{mi})$ the total whole-body dose via immersion and inhalation should not exceed 1 to $5 \mathrm{rem},(b)$ at the same distance, the radioiodine dose to a child's thyroid should not exceed 5 to $25 \mathrm{rem}$, (c) beyond 80 $\mathrm{kn}$ ( $50 \mathrm{mi})$, the total whole-body jose via all ingestion pathways should not exceed 1 to 5 rem, and (d) the radioiodine dose to a child's thyroid, via in restion, should not cxceded 5 to 25 rem at $80 \mathrm{knl}$. Doses calculated for a hypothetical I.Or'A at the Rancho Seco Nuclear Power Plant are less than $1 / 500$ or 0.2 percent of the Protective Acticn Guidelines at both 16 and $80 \mathrm{~km}$.

\section{Washout}

As mentioned earlier, no calculations were made of washout (due to rainiall) of the nuclices released. If it were raining at Rancho Seco during a loss-of-coolant accident, depsition and food pathway doses from particles would be larger near the power plant, perhaps by a factor of 10 (immersion and inhalation doses would be less). Doses farther downwind would be lower than if it were not raining. Seattered rain showers occurring over part of the area considered in this assessment would create hot spots in the surface deposition, resulting in isolated areas giving doses up to about a factor of 10 larger than those indicated in Table 6.

\footnotetext{
To our knowledge. there are no milk cows, beef eat tle, or truck gardens within the Sacramento metropolitan area; following an accidental release at Rancho Seco, both state and Federal authorities would closely monitor all food pathways in order to minimize the dose.
} 


\section{"Worst Case"}

For a loss-of-coolant accident, using the prescribed source terms (Table 3 ), the present assessment is believed to be, or to at least approach, a worst-case analysis for the Sacramento metropolitan area. A persistent and extensive fog in the Central Valley would present a worst-case scenario for the immediate vicinity of Rancho Seco, out to a radius of 5 to $10 \mathrm{~km}$. Fog in winter is common in both the San Joaquin and Sacramento Valleys; however, the near-surface winds are typically light $(\leq 1 \mathrm{~m} / \mathrm{s})$ at such times and of ten variable in direction. This would result in pooling of the effluent from a loss-of-coolant accident so that, with fog and light, variable $u$ inds, little or no dose would be received beyond $10 \mathrm{~km}$ from the reactor. When the fog dissipates and windspeeds increase, the effluent would move downwind as a large area source. As a consequence, the resulting doses farther from the reactor would de less than those given in Table $f$ and in the isopleth maps.

\section{Error Analysis}

A quantitative error analysis would be possible only if we ran the NATIIEM/ADPIC suite of codes many times, varying an important input parameter each tinte. We have done this in a limited sense during some of our past assesuments. However, it is too costly in terms of computer time to run a quantitative error analysis for each assessment. Consequently, based on past cxpcriencc, we can makc reasonable estimates about the accuracy of our results. The surfuce and upper-air observations are aciurate to the nearest 10 degrees and $0.5 \mathrm{~m} / \mathrm{s}$; measurement errors should have a negligible effect on our assessment, even considering that the nearest upper-air station (Oakland) is somewhat removed from the area of interest. Variations in other input parameters, including the top of the mixing layer and surface-roughness height, should affect our calculations by less than a factor of two. Many possible judgmental errors in sclecting code input parameters would tend to cancel each other.

Or.e of the largest sources of error lies in the selection of dose-conversion factors. So many variables are involved, especially in the food pathways, that differences of more than a factor of 10 can be found in the literature. However, our soirces for DCF, WASH-1400]0 and ORN $2-4992,11$ agree within a factor of 3. These sourens also agree well with the Dr'F used in Lawrence I.ivermore National l.aboratory's Plowshare Program in the eaily ] 970s.] 4

The leakage rates for a Joss-of-coolent accident, provided to us by SMUJ) 8 (Table 3), are another potentially significant error source; however, an assessment of errors in the containment leakage rate from a nuclear reactor is beyond the scope of this study.

With some credit for cancelling errors, the doses given in this report could be too low or ton high by, at most, a factor of five within $10 \mathrm{~km}$ of the reactor and by about a factor of three at greater uistances. This assumes that the winds and atmospheric stability are as used herein or, if different, would lead to a similar diffusion rate. The leakage rates are also assumed to be as given. 


\section{Comparison with Three Mile Island Accident}

On March 28, 1979, an accident at Lnit 2 of the Three Nile island nuclear power reactor, near Harrisburg, Pennsylvania, released a $\mathrm{mix}$ of racijunuclides into the atmosphere for several days." From the standpoint of dose, the most significant nuclide released was Xe-133. The total amount of $\mathrm{Xe}-133$ released was estimated at $1.2 \times 10^{7} \mathrm{Ci}$, about $85 \%$ of which was emitted during the first 24 hours. 15

For comparison, we have calculated the dose from whole body-immersion had the same amount $\left(1.2 \times 10^{7}\right.$ (i) of airborne Xe-133 been released at Rancho Seco over $2+$ hours, under the same meteorological conditions used in this report. These doses from he-133 iminersion are $340 \mathrm{millirem}$ at about $\mathrm{i} \mathrm{km}$ northwest oi Rancho Sceo and 8.f millirem within the Sacramento metropolitan arca. Cur analysis of a Rancton sceo I.OCA indicates doses from Xe-133, via immersion, of 0.27 millirem near the reactor and of 0.0068 milliren in the Sarramente metropolitan area.

Aceording to data provided by $M o o d a r d, 15$ the average release rate of $1-131$ released during the Three Mile Island aceident was $5.3 \times 10^{-6}(\% \mathrm{i} / \mathrm{s}$. If radioiodine wore relessed at this rate from Rancho Seco over a 24 -hour period, using the wind firles described earlier, th. maximum dose via the forage-cow-milk pathway $u t$ atinut $1 \mathrm{~km}$ downsind of the power plant would be 86 millirem. The largest dose within the Sacramento Metropolitan Area, from the forage-con-milk pathway, would tse $0 . \$ 1$ millirem. These values; should he eompared with tiose ontained in this report for a Rancho Seco $1.0(\mathrm{~A}$, namely, in rem near the power plant and i80 millirem within Sacramento.

\section{SUMMARY}

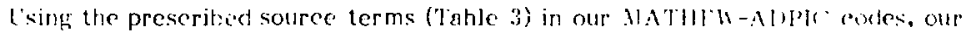
I $u(A$ dose calculations indicate values that are about one-fourth of faterial regulation limits. The doses are yll less than 0.2 pereent of the finvironmerlinl Protection Ageney's proter tive Action (judelines at both 16 and $80 \mathrm{hm}$ onnuind. the whole-body external gamma anc inhalation doses witlin the sucraniento metropolitan area are the only pathways directly affecting the population, and these doses are only a few millirem. About $1 \mathrm{~km}$ downuind of the Rancho Sece site, the maximum dose vit food chains is 70 rem. However, all maximum food-chain unses would be less than one iem if nilk were pooled through a cooperative, cows were. put on uncontaminated dry feed, eattle were not slaughtered soon atler exposure, and vegetables were consumes shortly after exposure (10 minimizc uptake through the root system) and were washed before consumption.

\footnotetext{
*The Three Mile Island (TNIl) accident was not the type of loss-of-coolant accident postulated by the Nuclear Regulatory Commission. Compared to Rancho Seco LOCA release rates, the Thil Xe-133 release rate was much larger. TMI's 1-131 relcase rate, however, was much smaller than the values given in Tah!e 3.
} 


\section{REFERENCES}

1. Lorenzen, Arndt, Climate of the Sacramento Valley Air Basin, State of California Air Resources Hoard, Division of Technical Services, (1974).

2. L.S. Department of Commerce, Fnvirenmental Science Services Administration, Clingtic Atlas of the L'nited States, L'. S. Covernment Printing Office, Washington, 1). r., (1968).

3. Jeiter from Roger Powers, Sacramento Municipa] l'tilities [Bistrict, June 25, 1459.

4. Sherman, ('hristine A., "A Mrss-Consistent Model for $h$ ind Fields Over complex Terrain," J. Appl. 11eteor. 17, 312-319, 1979.

5. Susiki, Y., "Somo Jusic Formalisms in Numerical Variational Analysis," Mon. แ1 pr. Rev., $98,875-883,1970$.

6. I.unge, Kolf, "AnPls - A Threc-limensiona! Particle-in-( cll Model for the 1)jepersat of Atmospheric Pollutants and Its Comparison to Regional "iracer Studies," J. Appl. Nleteor. 17, 320-329, 1979.

. l'etersm, liendall R., lodet V. Crawford, and leonard A. lawson, ('PS: A Continuous-Point-Source romputer rode for Plume lispersion ane Deposition Calculations, Iawrence I.ivermore l.aboratory, livermore, ('alilornit, LCRI.-52049, (1976).

8. Sucramento Municipal L'tilities Distriet, Rancho Secu Nuclear Cicnerating Stition, l'nit No. 1, Final Sufety Analysis Report, Sacramento, California, (l! 4 il, as amended).

9. Hol\%worth, (imorge ('., Mixing Heights, ind Speeds, and Polential for Lrban Air Pollution Throughout the Contiguous United States, finvironmental Protection Ageney, Office of Air Programs Pub ication No. AP-l01 (1972).

10. L'. S. Nuclear Regulatory Commission, Calculation of Reactor Accident conseguences Reactor Safety Study, WASH-1400 (NLRFG $75 / 014$ ), Hashington, I...., (1975), App. VI.

11. Killough, G, G, and l.arry R. Nckay, comp. A Nethodology for Calculating Kadiation Doses from Radioactivity Released to the Fnvironment, Oak Ridge National I aboratory, Oak Ridge, Tennessee, OR N I-4992 (1976).

12. Fnvironmental Protection Ageney, Manual on Protective Action Cuides and Protective Actions for Nuclear Incidents, Fnvironmental Protection Agency, $520 / 1 / 75 / 001$, liashington, D. C. 20460, (1975).

13. Nuelcar Regulatory Commission and Federal Emergency Management Agency, Criteria for Preparation and Fvaluation of Radiological Emergency Response Plans and Preparedness in Support of Nuclear Power Plants, NUREG 0654/FEMA-REP-I, Washington, D. C., craft report (1980). 
14. Schwartz, L. L., H. A. Tewes, W. L. Robison, and K. R. Peterson, "Potential Pathways to Man for Radionuclides from Excavation Applications of Peaceful Nuclear Explosives," Peaceful Nuclear Explosions IV, [A EA-TC-1-4/9, In "ernational A tomic Energy Agency, Vienna, Austria, 1975.

15. hoodard, Keith, Pickard, Lowe, and Garrett, Ine., Washington, D. C., unpublished manuseript (1979).

Jac

FI.W/0007F/000!F. 


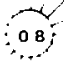

$\begin{array}{ccccc} & & \text { FREOUENCY } & 10 / 01 & \\ & i & 5 & 10 & \text { is } \\ \text { CALMS } & & & & \end{array}$

Fifure 1. Pererentage frequeney of $10-m$ directions from wete't the wind blows at Rancho Sreo for all fronths from lat to l\$?

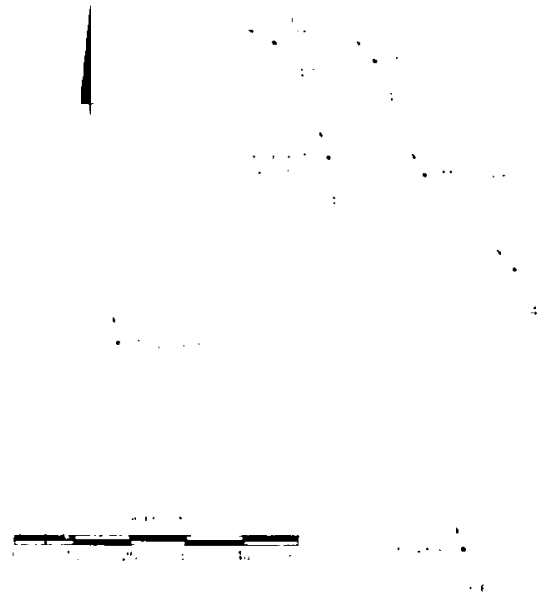

Figure 2. location of meteorological statiors used in NATHEW-ADPIC calculations. Arrows indicate wind directions at 2200 PST, November 19, 1978. Wind speeds ( $\mathrm{m} / \mathrm{sec}$ ) gre shown at the ends of the arrows. 

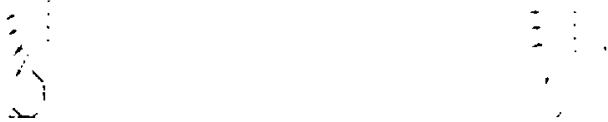

ligrure 3\%. Rrgional map ol dose from

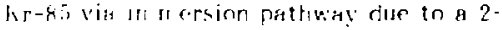

Figure 3b. Same as Fig. 3a, except

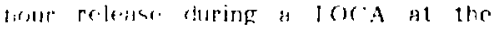

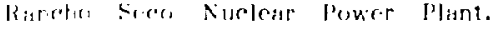
kropletlianer tI millirem.

Figure An. Kegional map of dose from I-l31 vas immersion pathway due to a 2 hour release during a I.OCA at the lizncho Seco Nuclear Pover Plant. Isopleths are in millirem.
Figure 4h. Same as Fig. ta, except release is 24 hours. 
Finurs ate Pererinnit matp of dore from

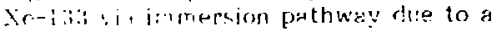

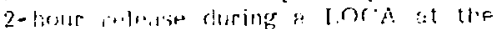

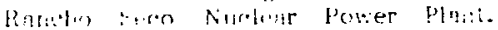
lioploth, an in u illersm. ligure 5b. Same as Fig. 5a, except release is 24 hours.

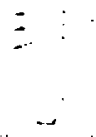

Figure 6a. Regional map of dose from rs-137 via immersion pathway due to a 2 -hour release during a I.OCA Ht the Rancho Seco Nuclear Power Plant. Isopleths are in millirem.
Figure 6b. Saine as Fig. 6a, except release is 24 hours. 

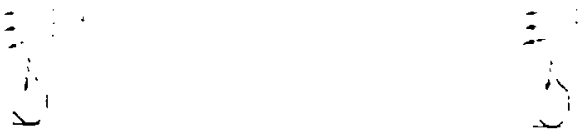

fifure it. Regional map of dose from all mureleie vig ipupicrsion pathway duc Figure ih. Sume ac rig. iz, except

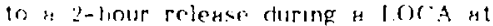
release is 24 hours. the Ranclio Seen Nuelear Pouer Plant. meplothe are m millirem.

Figure 8x. Regional map of dose from 1-131 vin ceposition pathwny lono day rxposurel due to a 2-hour relegse during "l.oc'A at the Rancho Seco Nuctear Power Plant. Isopleths are in millirem.

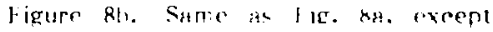
relence $: 2$ it hours. 
1. igure 44. Regional map of dose from ('s-137 via crpositicn pathway (one day (xposure) due to н 2 hour reiease during H I.CI'A Ht the Rancho Seco Nuclear Pouer Plant. Isopleths are in millirerr. ans

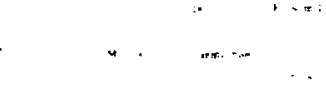

$\because$

Figure 9b. Same as Fig. 9A, except release is 24 hours.

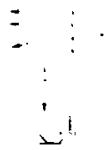

Figure Jua. Regional map of dose from Figure 10b. Same as Fir. 1Ga, except Sr-90 via inhalation pathway due to a 2- release is 24 hours.

$\mathrm{hr}$ release during a I.OCA at the Rancho Seco Nuclear Power Plant. isopleths are in nillirem. 


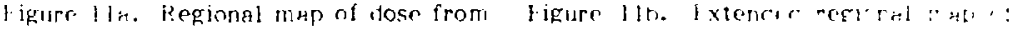

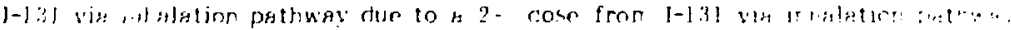

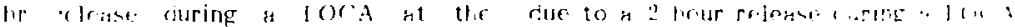

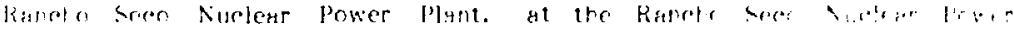

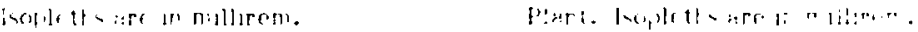

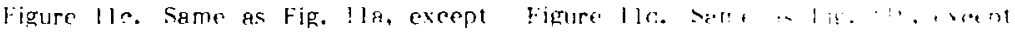
rolnuse is 24 hours. 


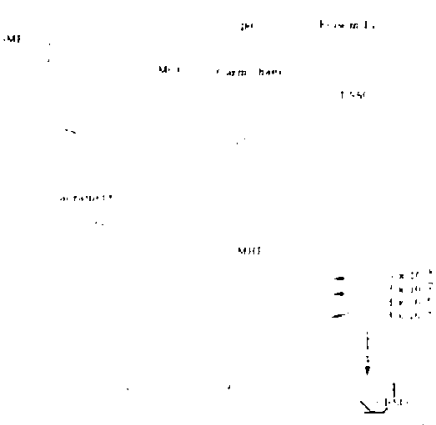

Fisure 12a. Regional map of dose from Cs-137 via inhalation pathway due to a $2-\mathrm{hr}$ release during a LOCA at the Rancho Seco Nuclear Power Plant. lsopleths are in millirem.

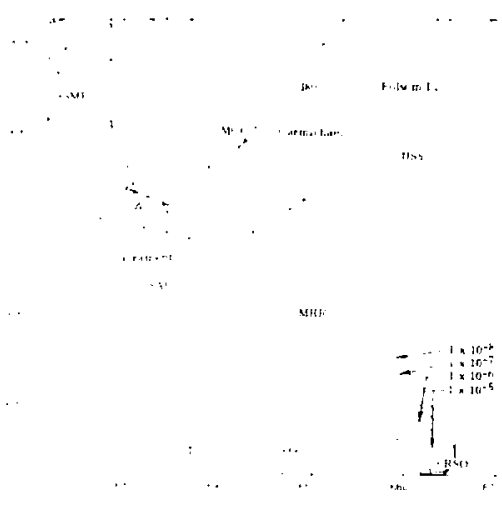

Figure 138. Regional map of dose from Sr-90 via forage-cow-milk pathway due to a 2-hour release diring a LOCA at the Rancho Seco Nuclear Power Plant. Isopleths are in millirem.
Figure 12b. Same as Fig. 12a, except release is 24 hours.

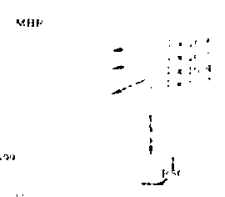




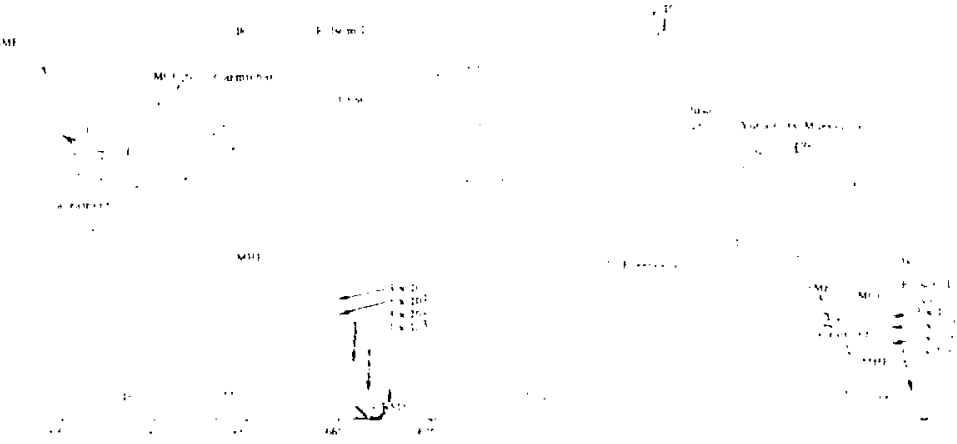

Figure 14a. Regional map of dose from 1-131 via forage-cow-milk pathwey dur. to a 2-hour rclease during a I.OCA at the Rancho Scco Nuclear Power Plant. Isopleths are in millirem.

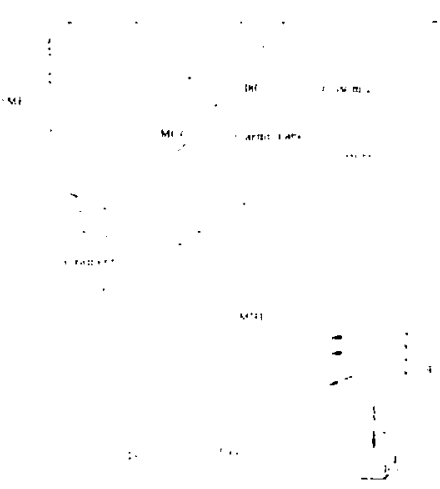

Figure 14b. Extended refional map of dose from I-13l via forage-cow-milk pathway duc to a 2 -hour release during a LOCA at the Rancho Scco Nuclear Power Plant. Isopleths are in millirem.
Figure 14c. Same as Fig. 14a, except release is 24 hours.
Figure 14d. Semc us Fig. 14h, cxcept relcrse is 24 hours. 


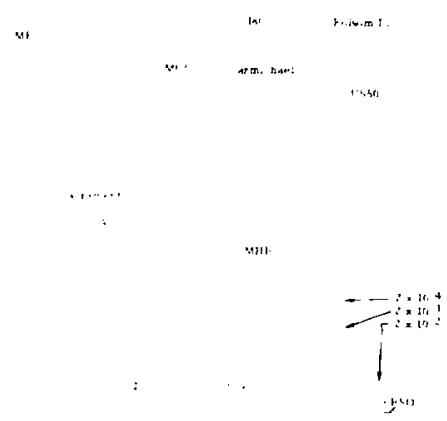

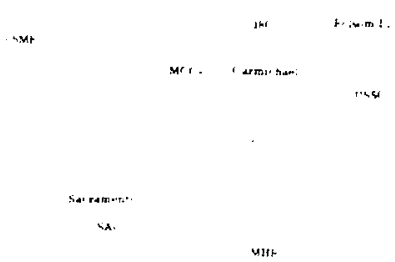

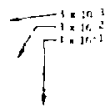

Figure 15a. Regional map of dose from Cs-137 via forage-cow-milk pathway due to a 2-hour release during a LOCA at the Rancho Seco Nuclear Power Plant. Isopleths are in millirem.
Figure 15b. Same as Fig. 15a, except release is 24 hours.

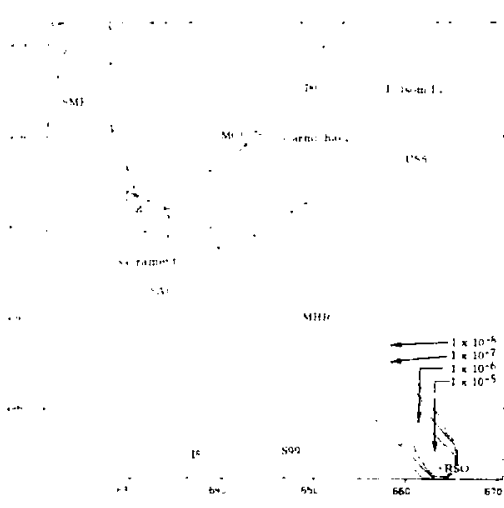

Figure I6a. Regional map of dose from $\mathrm{Sr}-90$ via pasture-meat pathway due to a 2-hour release during a LOCA at the Rancho Seco Nuclear Power Plant. Isopleths are in millirem.

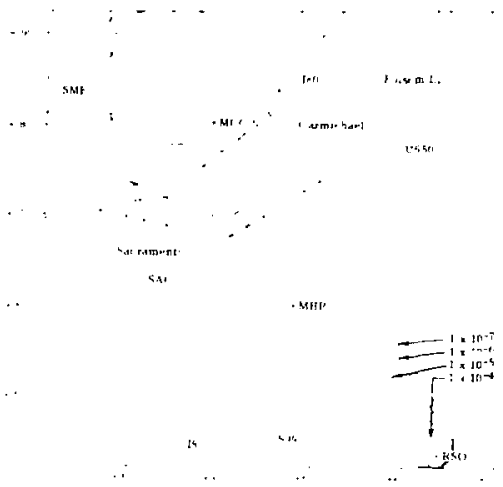

Figure 16b. Same as Fig. 16a, except release is 24 hours. 
4
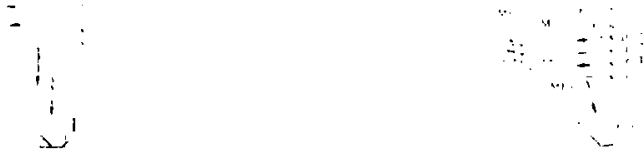

Figure 17a. Regional map of dose from 1-131 via pasture-meat pathu'ny due to a 2 hour relcase during a lor $A$ at the Rancho seco Nuclear Power Plant. Isopleths are in millirem.
Figure 17h. Extended regional map of dose from $[-13]$ via pasture-meat pathway due to a 2-hour relense during a I.OCA at the Rancho Seco Nuclear Power Plant. Isopleths are in millirem.
Fagure 17c. Same as Fig. lia, except releuse is 24 hours.
Figurs 17d. Same as rif. lith, except release is 24 hours. 
Figure 18a. Regional map of dose from Cs-137 via pasture-meat pathway due to a 2-hour release during a LOC.A at the Kancho Seco Nuclear Power Plant. Isopiethis are in millirem.

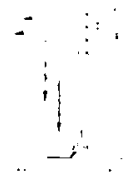

Figure 180. Same as Fig. 18a, except release is 24 hours.

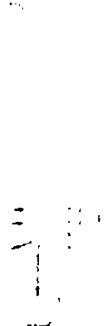

4
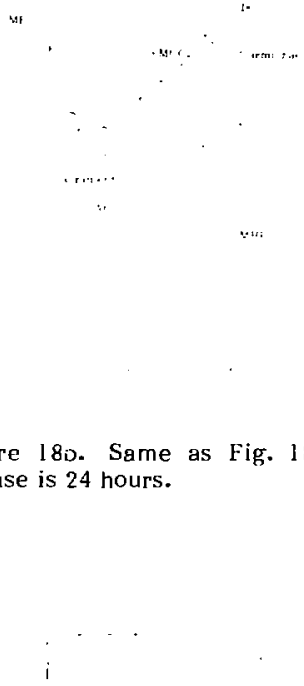

ง

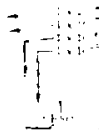

Figure 1 $\exists a$. Regional map of dose from Sr-90 via leafy-vegetable pathway due Figure 19b. Same as Fig. 19a, except to a 2-hour release during a J.OCA at release is 24 hours. the Rancho Seco Nuclear Power Plant. Isopleths are in millirem. 

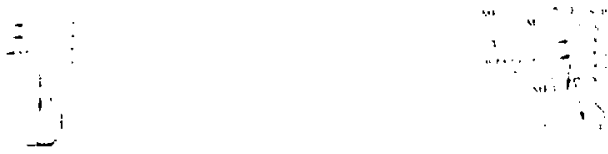

ligure 20a. Regional miap of dos? from 1-131 via logfy-vegetable pathway due to a 2-hour release during a I.OCA at the Rancho Seco Nuclear Power Plant. lsopleths are in millirem.
Figure 20h. Fxtended regional map of dose from $1-|3|$ via leafy-vegetarle pathway due to a 2-hour release during a I.OC $A$ at the Rancho Seco Nuclear power Flant. Isopleths are in millircm.

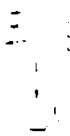

Figure 20c. Same as Fig. 20a, except Figure 20d. Same as Fig. 20h, except release is 24 hours. relegse is for 24 hours. 


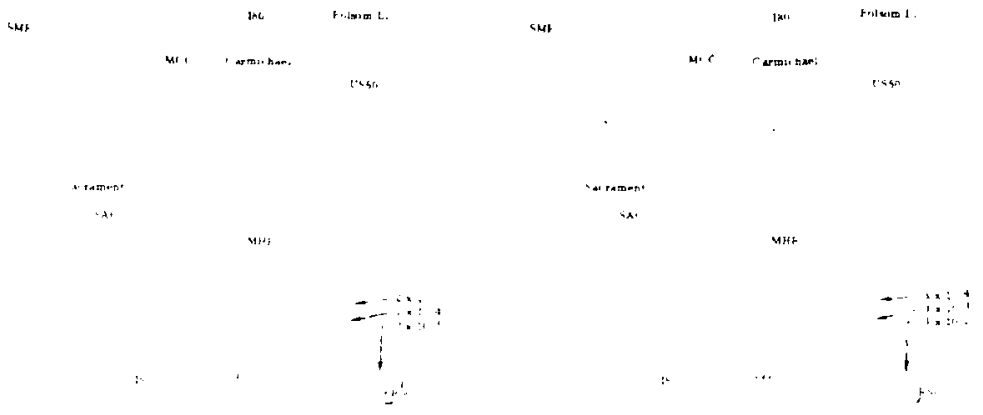

Fizure 2la. Regional map of dose from Cs-137 via lealy-vegetable pathway due to a 2-hour release during a LOCA at the Rancho Seco Nuclear Power Plant. Isopleths are in millirem.
Figure 2]b. Same as Fig. 21a, except release is 24 hours. 